\title{
A model of the glacial retreat of upper Rennick Glacier, Victoria Land, Antarctica
}

\author{
M. Meneghel, ${ }^{1}$ A. Bondesan, ${ }^{1}$ M. C. Salvatore, ${ }^{2}$ G. Orombelli ${ }^{3}$ \\ ${ }^{1}$ Dipartimento di Geografia "G. Morandini", Università di Padova, I-35123 Padova, Italy \\ ${ }^{2}$ Dipartimento di Scienze della Terra, Università di Roma "La Sapienza”, I-00185 Rome, Italy \\ ${ }^{3}$ Dipartimento di Scienze dell'Ambiente e del Territorio, Università di Milano-Bicocca, I-20126 Milan, Italy
}

\begin{abstract}
The morphology of the Lichen Hills in the upper section of Rennick Glacier, Victoria Land, Antarctica, is summarised as follows: (a) a top surface on the volcanic rocks with scattered erratic blocks; (b) an exhumed Kukri Peneplain, sculptured with roches moutonnées with striae and crescentic gouges on which lie moraines and patches of drift of mainly volcanic rocks; (c) a granitic bedrock eroded by glaciers into sharp peaks and cirques, on top of which there is a glacial drift attributable to ancient blue-ice areas higher than those observed at present and which may be correlated with the Terra Nova drift (Late Wisconsin); (d) various Holocene ice-cored moraines that are pushed to the lee side of the nunataks and are often banded in strips of different lithology. The bands of the Holocene moraines are related to the rock complexes that became exposed from the ice during the lowering of the surface of the glacier. Analysis of the lithology and pattern of the supraglacial debris, as well as of the blue-ice areas, allows us to construct a depositional model for the moraines, and to relate the glacial drift to blue-ice areas existing since the Last Glacial Maximum (LGM). The proposed model shows the different stages of recession of upper Rennick Glacier that are also valid for similar situations observed in northern Victoria Land. A surface lowering of upper Rennick Glacier of several hundred metres shows that significant changes have occurred at the Pacific edge of the East Antarctic ice sheet since the LGM.
\end{abstract}

\section{INTRODUCTION}

Located in Victoria Land, at the limit between a more glaciated icefield region with valley glaciers to the north and a less glaciated area (leading to the Dry Valleys) with outlet glaciers to the south, upper Rennick Glacier basin is considered of particular interest for the glacial history of the East Antarctic ice sheet (Denton and others, 1986). Rennick Glacier (Fig. 1) flows from the Transantarctic Mountains in a northnorthwesterly direction into the Southern Pacific Ocean. The western upper section of the glacier receives ice from Rennick Névé and from Talos Dome. In this upper section of the glacier several nunataks emerge from the ice, where geomorphic observations can help to trace the history of the glacier (Fig. 2). In this paper we discuss mainly a geomorphological survey of the nunataks of the Lichen Hills. Icesurface levels higher than at present were reconstructed from the evidence of erosional trimline, glacial striae, erratics and glacial deposits in the ice-free areas. A crucial and not yet resolved problem is the age of the upper limit of glaciation, and of the polished and striated surfaces, as well as the history of the glacial shrinkage from the Last Glacial Maximum (LGM).

At the foot of the outcropping hills, where blue ice is present, supraglacial drift often shows bands of different lithology, with light-coloured granitic rocks alternating with dark-coloured volcanic rocks. We inferred that the formation of the strips was due to the progressive reduction of the ice from its last maximum level to the present, in conjunction with the exposure of different rock units. The lowering of the glacier surface is shown by scattered, slightly weathered, erratic blocks on the top of the hills and by glacial deposits

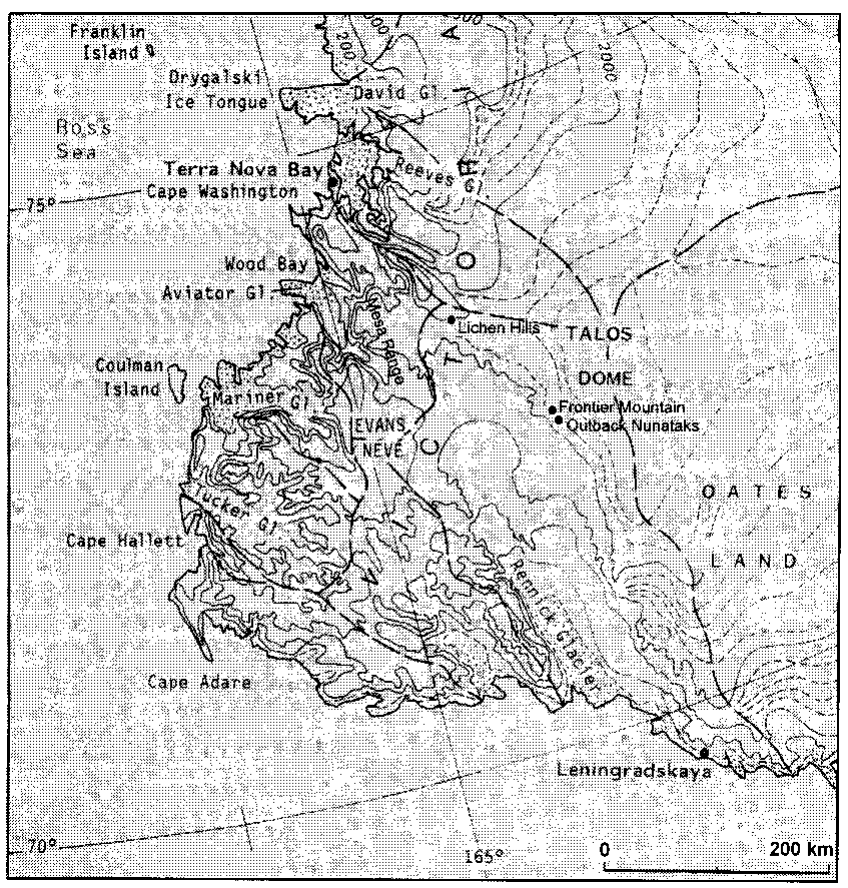

Fig. 1. Rennick Glacier and northern Victoria Land. 


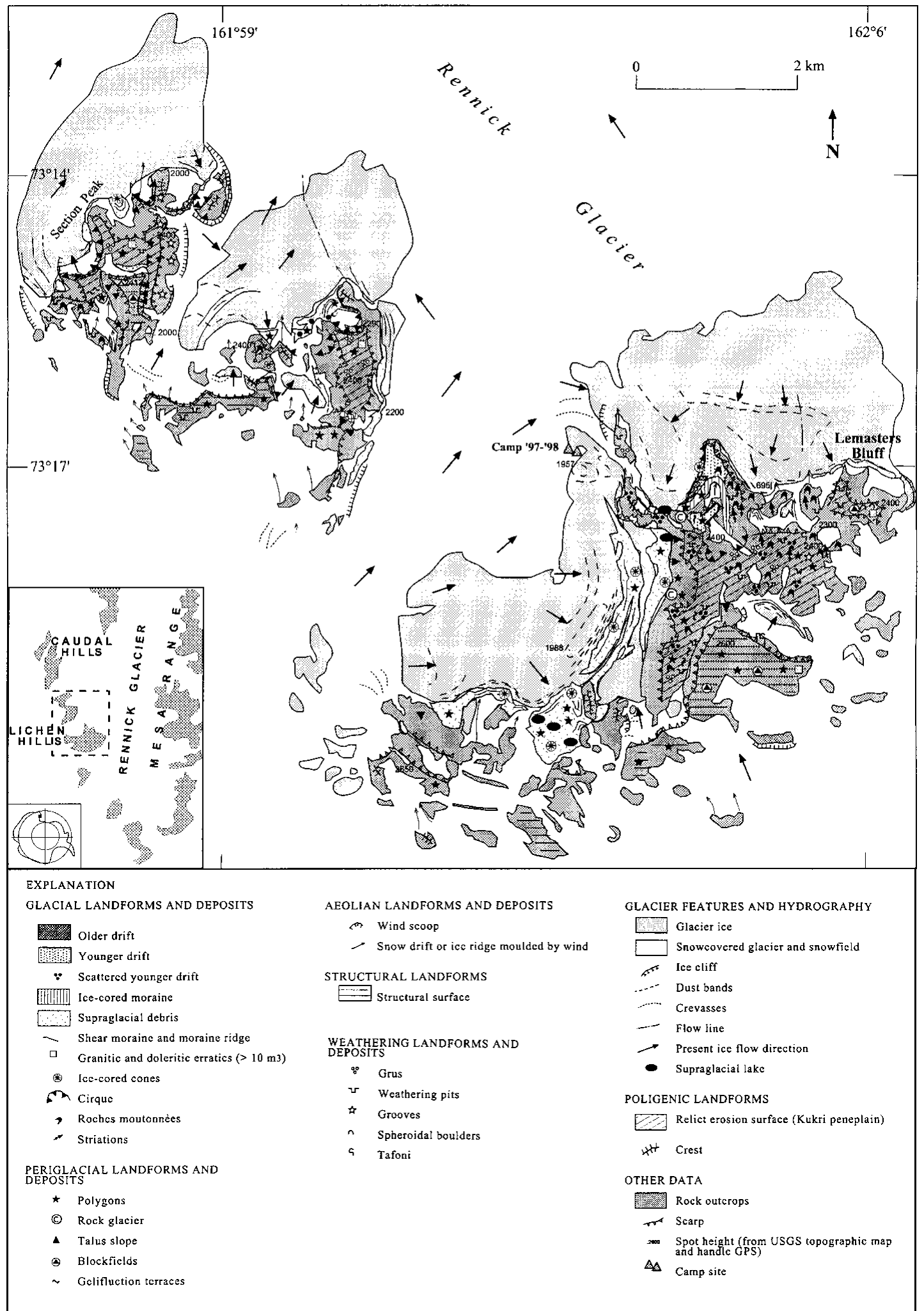

Fig. 2. Geomorphological sketch map of the Lichen Hills, upper Rennick Glacier.

found at various levels. Polished and striated rocks with crescentic gouges are frequent on the granitic surfaces (Fig. 2).

The glacial reduction model proposed in this paper is derived from the investigations carried out by the authors during field expeditions in 1993-94, 1995-96 and 1997-98, with camps in upper Rennick Glacier region. Meteorite research was carried out at Frontier Mountain, along with investigations on the blue-ice areas of the Outback Nunataks and detailed geomorphological and glaciological surveys of the Lichen Hills and Section Peak.

\section{GEOLOGIC AND GEOMORPHOLOGIC FRAME- WORK}

The bedrock geology of the upper Rennick Glacier area has been investigated during numerous expeditions; in this paper we refer to the geological map published by Carmignani and others (1988). The glacial history has been studied by many researchers, including Mayewski (1975, 1982), Mayewski and others (1979), Denton and Hughes (1981), Denton (1982), Denton and others (1986), Höfle (1989), Orombelli and others 
(1990), Van der Wateren and Verbers (1992a, b) and Delisle (1993). From the literature one can deduce that in the past some of the mountains in the upper Rennick Glacier area were overridden by ice. For example, glacial striae were found by Höfle (1989) at the top of Frontier Mountain at $2804 \mathrm{~m}$ a.s.l. and by Denton and others (1986) on the upper surface of Miller Butte at 2600 ma.s.l., while erratics were observed on the top surfaces of the Lichen Hills. However, the age at which the overriding by ice took place has not been satisfactorily established (Denton and others, 1986; Orombelli and others, 1990).

Rennick Glacier is a large glacier at the western margin of northern Victoria Land and it flows in a north-northwesterly direction into the Southern Pacific Ocean along an extensional graben structure of the Transantarctic Mountains. It is $>300 \mathrm{~km}$ long, up to $35 \mathrm{~km}$ wide in its trough sector and drains a basin of about $54000 \mathrm{~km}^{2}$. In its upper section, Rennick Glacier drains from the east the ice coming from Evans Névé and the Mesa Range. From the west the ice comes from Rennick Névé and from Talos Dome, a culmination of the East Antarctic ice sheet. In the upper section of the glacier, isolated nunataks outcrop from the ice, whilst other buried mountains can be inferred from bulges, crevasses and other features on the ice surface. The rocks of the nunataks belong to two main complexes. The lower complex is composed of granitic rocks of the Granite Harbour Intrusives (Ordovician) and of high-grade metamorphics of the Wilson Terrane, possibly pre-Cambrian, which are cut by a horizontal erosional surface known as the Kukri Peneplain. The second complex of rocks, the Ferrar Supergroup volcanics and the Beacon Supergroup sandstones, was deposited over this erosional surface. The Ferrar Supergroup includes the Kirkpatrick Basalt, generally interpreted as lava flows, and the Ferrar Dolerite sills. The Beacon Supergroup outcrops close to the bottom of the Ferrar Supergroup as the Section Peak Formation, and it is a thin layer of sandstone, locally fossiliferous, deposited by braided streams. The volcanics are darkcoloured, whilst the sandstone, granitic and metamorphic rocks are light-coloured, so the debris coming from each can be clearly identified by the strong contrast in colours.

The nunataks of the west side of the uppermost Rennick Glacier are aligned in a south-southeasterly-north-northwesterly direction and decrease in altitude from about

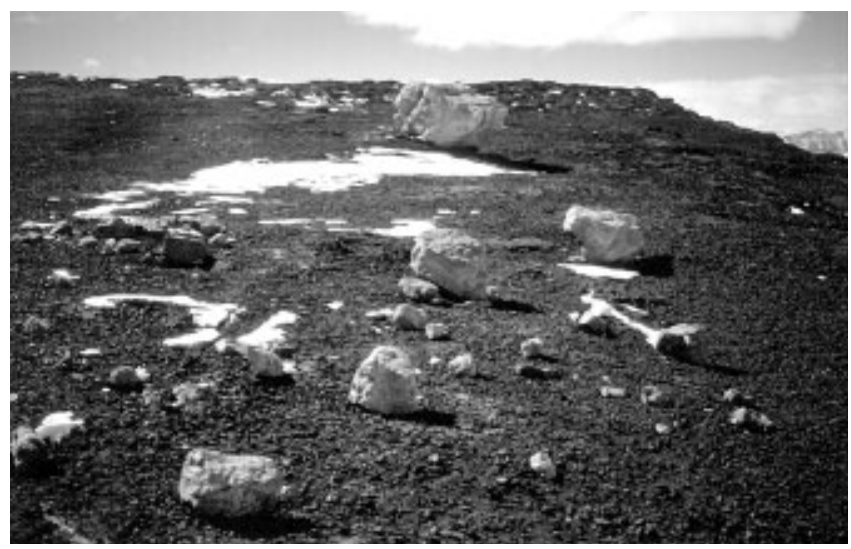

Fig. 3. Slightly weathered, angular to subangular erratic blocks of granite resting on weathered Ferrar Supergroup bedrock, on the tabular summit of the Lichen Hills. The blocks are comparable to the exposed granitic blocks of the Terra Nova drift (Late Wisconsin) in northern Victoria Land due to the absence of staining, oxidation patinae and cavernous weathering.
$3000 \mathrm{~m}$ to the south to $2400 \mathrm{~m}$ to the north. The nunataks are separated by glacial flows coming from the ice divide between the Rennick Glacier and Priestley Glacier basins, and from Rennick Névé.

The nunataks have a uniform morphology, with the volcanic layers creating a flat-topped, cuesta-like form, partially covered by ice. The eastern slope of the front of each cuesta is steep in its upper part, mainly where columnar basalts outcrop. The slope is interrupted where the erosion exhumed the Kukri Peneplain and formed structural terraces. Where the erosion has sculptured the granitic and metamorphic rocks, an Alpine morphology with peaks and saddles is present. In plan view a complex morphology can be observed, with deep cirque-shaped gulfs on the northeast side whose bottoms are filled by blue-ice tongues flowing back from Rennick Glacier.

\section{THE LIGHEN HILLS}

The Lichen Hills are composed of two distinct nunataks, divided by a glacial flow. To the north there is Section Peak, which is itself divided into two parts by a small glacier flowing north-northeast. To the south of the Lichen Hills proper is an arch-shaped hill (in plan view) with the concavity to northwest, whilst a slope with three spurs faces Rennick Glacier. The eastern spur is called Lemasters Bluff. The spurs embrace two gulfs, with the western one more deeply developed. Blue ice enters these two gulfs from Rennick Glacier where it is strongly ablated by katabatic wind, blowing mainly in a northerly direction. This can be clearly seen in the western gulf, where the blue-ice lobe slopes to the south and forms a closed depression with a small frozen lake at its snout. The location and extent of the blue-ice areas are directly related to the prevailing wind direction and the topography; on the lee side of the nunataks the strong atmospheric turbulence enhances ablation, forcing the ice to converge and to flow back.

The morphology is strongly influenced by the structural conditions. The top of the hills comprises wide tabular flats following the attitude of the volcanic layers. Here, where the surface is ice-free and covered by debris, a net of periglacial polygons and block fields has developed. On bare rocks, weathering pits are present, and near to the terrace border there are locally brittle chiselled forms a few tens of $\mathrm{cm}$ high. On the top surface of the Lichen Hills scattered, little-weathered granitic erratics were found (Fig. 3). Towards Rennick Glacier the layers of the Ferrar Supergroup form very steep slopes that become vertical where columnar joints are present. Scree cones and talus cover the lower part of the slope. Near the base of the volcanic rocks, an outcrop of sandstone layers of the Beacon Supergroup is observed (Di Giulio and others, 1997). Their thickness is small compared to that of the volcanic rocks, although locally the sandstone forms structural walls.

Locally, under the slope on the volcanic rocks, a terrace has developed on the exhumed Kukri Peneplain. The surface is gently undulating and the rock is deeply weathered, with pits and pseudo-karstic grooves. In some places the surface was moulded by the ice as roches moutonnées with polished surfaces, striae and crescentic gouges, and is covered by scattered glacial drift. A few moraines of volcanic rocks deposited by local glaciers were detected on these terraces. All this evidence suggests an old morphology, deeply affected by weathering and only slightly modified by recent glacial processes. 


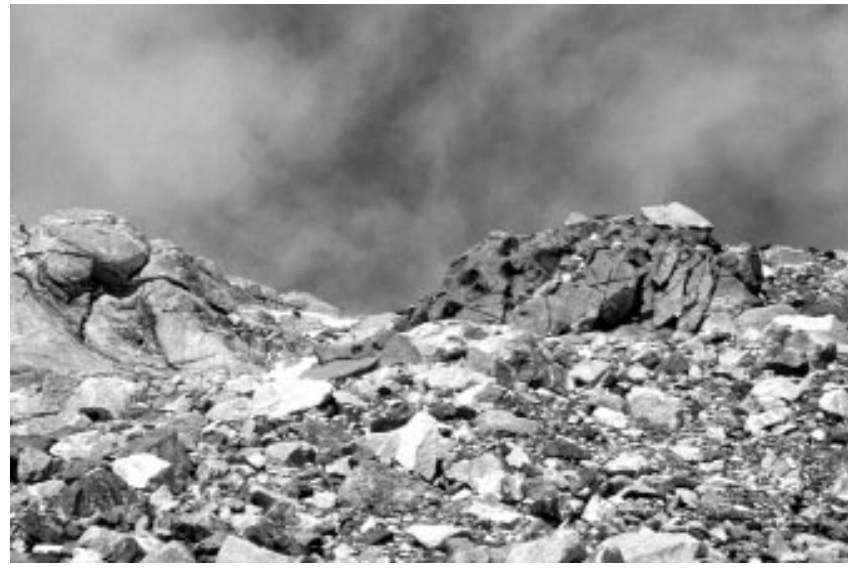

Fig. 4. Late Wisconsin glacial drift deposited by a blue-ice tongue from Rennick Glacier on weathered glaciated granite bedrock, west of Lemasters Bluff. Notice the fresh angular clasts of granite and a perched block on a bedrock knob.

The terraces on the Kukri Peneplain have steep slopes and rock walls down to the present level of the Rennick Glacier ice. Where the erosion of these slopes was greater, an alpine morphology with peaks and sharp arêtes developed, as in the northern part of Section Peak, in the spur near the 1997-98 camp and in the ridges of the Caudal Hills. Thick glacial deposits can be seen on these slopes, and a belt of glacial drift on the spur west of Lemasters Bluff is of particular interest (Fig. 4). It is composed of a clast-supported diamicton with angular and subangular clasts of granite, metamorphic rocks, dolerite and Beacon sandstone. Clasts are fresh and little-stained, and the sandy matrix is olive grey in colour. The surface is unstable and a network of coarse polygons is often present. Perched blocks are common, locally directly resting on weathered and oxidised glaciated granite bedrock. On the basis of both the morphology and the low degree of weathering, the glacial drift near Lemasters Bluff can be correlated with the Terra Nova drift described on the contiguous coastal area by Orombelli and others (1990) and attributed to the Late Wisconsin on the basis of radiocarbon dates.

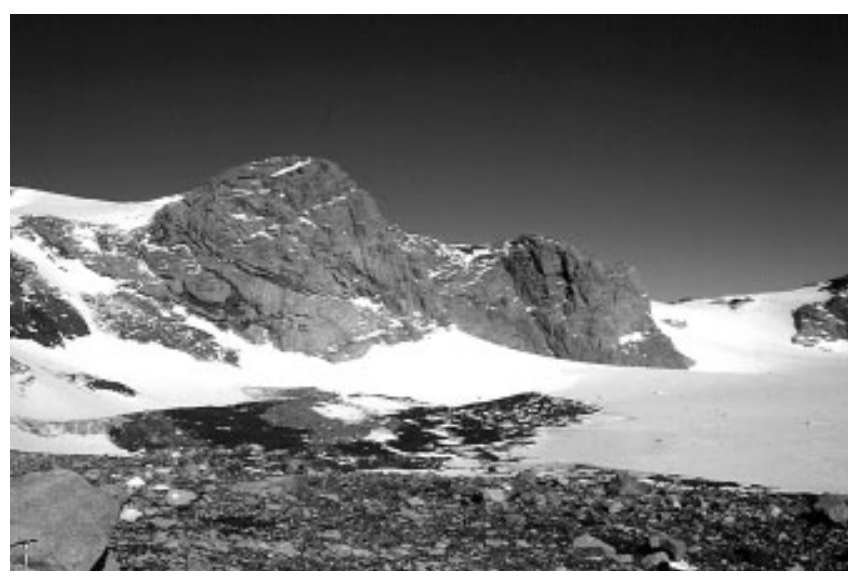

Fig. 5. Holocene ice-cored moraines at the base of the north slope of Section Peak. Dark-coloured volcanic debris and lightcoloured granitic debris form parallel bands, suggesting a provenance from progressively exposed bedrock walls of different lithology during Late-glacial and Holocene ice-surface lowering.
We deduced that the belt of glacial drift on the spur west of Lemasters Bluff was deposited by a blue-ice glacial tongue coming from Rennick Glacier and was stranded against the northern slope of the Lichen Hills. The process is similar to that presently acting at a lower elevation. Under the belt of glacial drift, where it forms a thin, discontinuous veneer, an older drift is locally preserved, as can be inferred by the greater oxidation of the clasts and of the sand matrix, and by the presence of salt flecks. The two drifts suggest a complex glacial history, with repeated fluctuations of the ice level.

There are frequent patches of supraglacial debris with parallel ridges resting on blue ice (ice-cored moraines) near the base of the hill slopes. Distinct strips of different lithology can be observed, mostly detectable by the difference in colours (Fig. 5); this can be seen even on aerial photographs. The direction of the ridges is parallel to that of dust bands in the blue ice, both perpendicular to the direction of the ice flow.

Ice-cored moraines are common beside blue-ice glacier margins in the upper Rennick Glacier area and near the margins of outlet glaciers, ice shelves and small local glaciers in the Terra Nova Bay region. They have been attributed to the Holocene on the basis of radiocarbon dates (Denton and others, 1986; Orombelli and others, 1990).

\section{A MODEL OF GLACIAL REDUCTION}

Based on the general morphology and the existence of icecored banded moraines, a model is proposed of the glacial
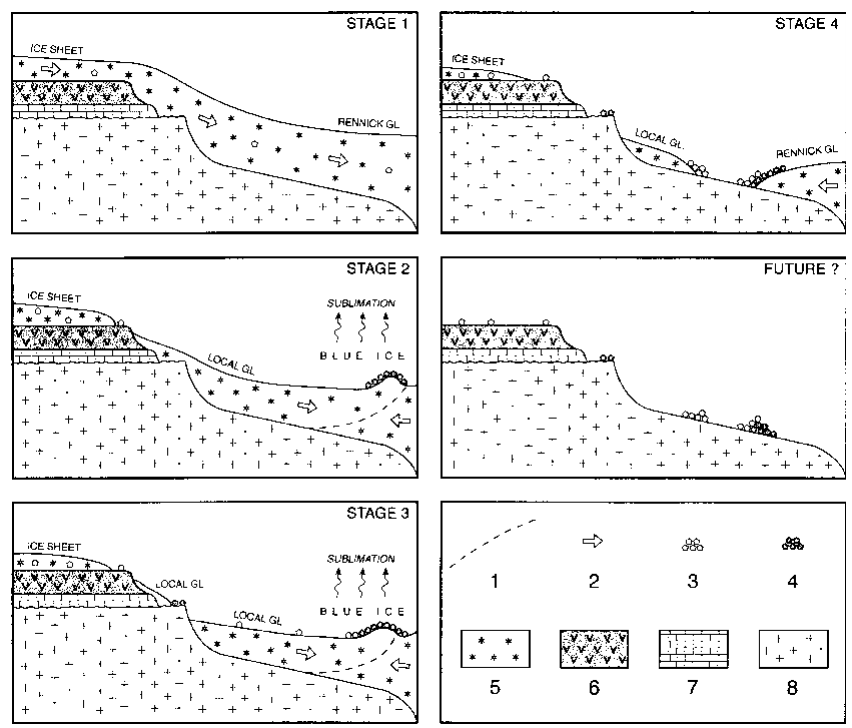

Fig. 6. The proposed model for the glacial reduction since the LGM at the Lichen Hills, leading to the formation of Holocene ice-cored moraines with bands of different rock types. Stage 1 shows the situation during the LGM when the Lichen Hills were covered by ice from the plateau, no blue-ice areas were present and the ice was discharged entirely down-valley. Stages 2 and 3 show the initial phase of glacial reduction with the formation of blue-ice areas, the development of local glaciers still merging into Rennick Glacier and the formation of ice-cored banded moraines. Stage 4 depicts the present situation, with small local glaciers and a blue-ice lobe from Rennick Glacier flowing backward on the lee side of the nunatak. A possible further glacier reduction would lead to the deposition of moraine ridges with bands of different rock types. 
reduction since the LGM. Ignoring the problems of the older glacial history related to the upper limit of glaciation (trimline), the older drifts and the poorly preserved or, locally, perfectly preserved glacial striae, we consider only the glacial changes that have occurred since the Late Wisconsin. The progressive glacial reduction is sketched in Figure 6.

Stage 1 shows the situation corresponding to the LGM, with the ice thicker than at present. The presence of slightly weathered granitic erratics on the top surface of the Lichen Hills is evidence of a glacial advance, although we did not find any evidence of a complete overriding of the nunataks. The extent of the glacial advance is difficult to establish, for several reasons: (a) the ice sheet covering the nunataks should have been very poor in sediment load, so it may not have left any erratics; (b) the possible presence of volcanic glacial drift is hard to detect because of the homogeneous lithological composition of the rock; (c) volcanic formations rarely preserve glacial erosional forms, such as striae and roches moutonnées. The presence of fine chiselled rocks along the rim of the top surface reveals a prolonged exposure to weathering. This leads us to believe that these forms were created before the LGM and that during the LGM the Lichen Hills may have been only partially covered by ice from the plateau, with ice-free areas remaining. During the LGM, Rennick Glacier would have been higher than at present and the difference in height between Rennick Glacier and the plateau surface to the west-southwest would have been less. In this situation the turbulence necessary for the creation of blue-ice areas would not have been generated by the katabatic wind, and the ice was entirely discharged down-valley.

Stage 2 shows the initial phase of glacial reduction. On top of the higher flat surface, some areas became ice-free and rare erratics were deposited. Glaciers flowing through the summits, or originating from the nunataks, transported downhill mainly volcanic debris falling from the ice-free walls. The increased difference in height between the plateau top and the Rennick Glacier valley resulted in the formation of larger blue-ice areas. In some cases, the ice flowing from local glaciers could have been completely removed by sublimation. In this case, backward-flowing blue-ice lobes from Rennick Glacier with marginal ice-cored moraines developed.

Stage 3 shows a further glacial reduction where a local glacier has divided into two parts: the upper glacier deposited glacial drift composed of volcanic rocks on the exhumed Kukri Peneplain, and the lower glacier generated glacial drift consisting of blocks coming from the exposed walls of granitic and metamorphic rocks. In this way, a new band of the icecored moraine formed, which is composed of light-coloured rocks. The disposition of these banded moraines with convexity uphill in some cases, downhill in other cases, was controlled by the interaction between the local glacier and Rennick Glacier, according to the dynamics illustrated by Chinn (1994) for the glaciers of the Convoy Range.

Stage 4 shows a further step in the retreat of the glacier, corresponding to the present. The small upper local glacier on the terrace has disappeared, whilst a gap appears between the lower local glacier, which is forming a frontal moraine composed of granitic drift, and the Rennick Glacier lobe, which has a frontal moraine derived from the icecored moraine from stage 3 .

A possible future stage showing further glacial reduction could lead to the following situation, from top to bottom (as already partially realised on the slopes west of Lemasters Bluff): scattered erratics on the summit plateau;

drift of volcanic rocks on the Kukri Peneplain terrace;

moraine ridges, convex in opposing directions, on the lower granitic rocky slope: the most elevated, convex downhill, built up by local glaciers, and the less elevated, convex uphill, deposited by inset tongues of Rennick Glacier due to the katabatic-wind ablation of the base of the rocky slopes (blue-ice areas).

\section{GONCLUDING REMARKS}

The morphology of the nunataks outcropping in the area of upper Rennick Glacier is strongly controlled by the structure. On the western side, the nunataks have a step-like profile and a tabular aspect, with the top surface corresponding to the volcanic layers. Lower down, terraces correspond to the exhumed surface of the Kukri Peneplain. On the slope of the volcanic rocks, the sandstone layers belonging to the Beacon Supergroup form small walls, and other vertical walls correspond to the Kirkpatrick Basalts, which show typical columnar joints.

The glacial forms are subordinate, with frequent niches resembling glacial cirques, whose origin nevertheless is not necessarily glacial, as suggested by the similar forms of the Dry Valleys (Denton and others, 1993). Roches moutonnées are diffused and well preserved on Granite Harbour Intrusives. During the LGM the ice was at a higher elevation than now. It is likely that some of the top surfaces were icefree, as delicate weathering forms are locally preserved, which probably required a much longer formation period than the Holocene; these forms would have been destroyed if overridden by the glacier flow.

The presence of glacial drift with different stages of weathering in the northern sector of the Lichen Hills is evidence of repeated fluctuations of the blue-ice lobes produced by Rennick Glacier, with the deposition of a younger drift over an older drift. On the slope to the west of Lemasters Bluff a belt of glacial drift was deposited by a glacial lobe from Rennick Glacier when the glacier was at a higher elevation than now. The presence of such a drift is evidence of the existence of a blue-ice surface similar to the present one. Its elevation (up to about $2100 \mathrm{~m}$ ) highlights a phase of reduction of Rennick Glacier during the Late Wisconsin to the Holocene, and represents the most elevated record of a blueice area in the Lichen Hills.

At the LGM the surface of Rennick Glacier will have been higher than at present, but possibly lower than $2600 \mathrm{~m}$, which is the height of the erratics deposited onto the summit surface of Lichen Hills by the inland ice. Considering the present ice-surface elevation, for there to be at least a partial overriding of the Lichen Hills during the LGM, an increase of about $200 \mathrm{~m}$ in the ice surface would have been necessary, while Rennick Glacier in this sector could have been several hundred metres higher than now. This points to larger late Quaternary ice-surface fluctuations in this internal part of northern Victoria Land than previously considered (Orombelli and others, 1990; Delisle, 1993), at least near the nunataks, where reversed slopes of the blue-ice lobes developed.

The presence of banded floating moraines of different lithology is explained by the progressive outcropping, during the lowering of the ice surface, of initially volcanic and later 
granitic rocks, according to the model shown in Figure 5. The preservation of the ice-cored moraines elongated in bands is linked to the presence of leeward blue-ice areas, affected by intense sublimation. Ablation measurements performed on the Frontier Mountain blue ice show an average value of $0.05 \mathrm{~m} \mathrm{a}^{-1}$ w.e.

The absence of meteorites in the Lichen Hills blue-ice areas is possibly attributable to the reduction or disappearance of the blue-ice meteorite traps during full glacial times, when all the ice was discharged toward the ocean.

\section{ACKNOWLEDGEMENTS}

This work was carried out within the framework of the Italian Programma Nazionale di Ricerche in Antartide, core project 2a, "Glaciology and Paleoclimate", and was financially supported by Ente per le Nuove Tecnologie, l'Energia e l'Ambiente through a joint research programme on Antarctic glaciology with the University of Milan.

\section{REFERENCES}

Carmignani, L. and 7 others. 1988. Geology of the Wilson Terrane between David and Mariner Glaciers, Victoria Land (Antarctica). Mem. Soc. Geol. Ital., 33, 77-97.

Chinn, T. J. 1994. Glacier disequilibrium in the Convoy Range, Transantarctic Mountains, Antarctica. Ann. Glaciol., 20, 269-276.

Delisle, G. 1993. Global change, Antarctic meteorite traps and the East Antarctic ice sheet. F. Glaciol., 39(132), 397-408.

Denton, G. 1982. Late Quaternary geology of the Rennick Glacier area, northern Victoria Land. Antarct. F. U.S., 17(5), 49-51.
Denton, G. H. and T. J. Hughes, eds. 1981. The last great ice sheets. New York, etc., John Wiley and Sons.

Denton, G., J. Bockheim, S. Wilson and C. Schlüchter. 1986. Late Cenozoic history of Rennick Glacier and Talos Dome, northern Victoria Land, Antarctica. In Stump, E., ed. Geological investigations in northern Victoria Land. Washington, DC, American Geophysical Union, 339-375. (Antarctic Research Series 46.)

Denton, G. H., D. E. Sugden, D. R. Marchant, B. L. Hall and T. I. Wilch. 1993. East Antarctic ice sheet sensitivity to Pliocene climatic change from a dry valleys perspective. Geogr. Ann., 75A(4), 155-204.

Di Giulio, A., R. Casnedi, A. Ceriani, A. Ortenzi and A. Rossi. 1997. Sandstone composition of the Section Peak Formation (Beacon Supergroup, northern Victoria Land, Antarctica) and relations with the Ferrar Group Volcanics. In Ricci, C. A., ed. The Antarctic region: geological evolution and processes. Siena, Museo Nazionale dell'Antartide, 297-304. (Terra Antarctica Publication.)

Höfle, H.-C. 1989. The glacial history of the Outback Nunataks area in western north Victoria Land. Geol. Jahrb., Ser. E, 38, 335-355.

Mayewski, P. A. 1975. Glacial geologic investigations of upper Rennick Glacier region, northern Victoria Land. Antarct. f. U.S., 10(4), 164-166.

Mayewski, P. A. 1982. Upper Rennick ice mass fluctuations study. Antarct. F. U.S., 17(5), 51-52.

Mayewski, P. A., J.W. Attig, Jr and D. J. Drewry. 1979. Pattern of ice surface lowering for Rennick Glacier, northern Victoria Land, Antarctica. $\mathcal{F}$. Glaciol., 22(86), 53-65.

Orombelli, G., C. Baroni and G. H. Denton. 1990. Late Cenozoic glacial history of the Terra Nova Bay region, northern Victoria Land, Antarctica. Geogr. Fís. Din. Quat., 13(2), 139-163.

Van der Wateren, F. M. and A. L. L. M. Verbers. 1992a. Cenozoic glacial geology and mountain uplift in northern Victoria Land, Antarctica. In Yoshida, Y., K. Kaminuma and K. Shiraishi, eds. Recent progress in Antarctic earth sciences. Tokyo, Terra Scientific Publishing Co., 707-714.

Van der Wateren, F. M. and A. L. L. M. Verbers. 1992b. Cenozoic glaciation of the Rennick Glacier area, the Everett Range and Yule Bay area, north Victoria Land, Antarctica. Polarforschung, 60(2), 1990, 73-77. 